\begin{tabular}{ll|l} 
Volume & $: 7$ & E-ISSH: 2656-940X \\
Nomor & $: 3$ & P-ISSH: 2442-367K \\
Bulan & $:$ Agustus & URL:jurnal.ideaspublishing.co.id \\
Tahun & $: 2021$ & U.
\end{tabular}

\title{
Dampak Aliran Dana Asing terhadap Fluktuasi Harga Saham \\ (Studi pada Saham-Saham dalam Kelompok JII-70)
}

\author{
Nurharyati Panigoro \\ Universitas Negeri Gorontalo \\ Pos-el: nurharyati@ung.ac.id
}

DOI: $10.32884 /$ ideas.v7i3.448

\begin{abstract}
Abstrak
Derasnya aliran dana asing yang masuk ke pasar modal Indonesia membuat meningkatnya nilai kapitalisasi di pasar modal. Transaksi asing terhadap suatu saham juga akan menjadi sinyal positif bagi investor dalam menilai kualitas fundamental suatu saham. Penelitian ini bertujuan untuk melihat dampak aliran dana asing (beli dan jual) terhadap fluktuasi harga saham. Sampel yang digunakan dalam penelitian ini sebanyak 10 perusahaan yang diambil dari daftar kelompok saham-saham yang masuk dalam Jakarta Islamic Index (JII). Data yang digunakan berupa data transaksi posisi asing dan harga penutupan saham pada periode harian selama bulan Oktober-Desember 2020. Dengan menggunakan teknik regresi data panel diperoleh kesimpulan bahwa posisi jual-beli asing memberikan pengaruh yang positif dan signifikan dalam perubahan harga saham perusahaan. Pembelian asing akan mampu memberikan efek kenaikan harga saham, demikian pula sebaliknya.
\end{abstract}

\section{Kata Kunci}

transaksi asing, perubahan harga saham

\begin{abstract}
Swift flow of foreign funds into the capital market has increased the capitalization of transactionin the stock market. Foreign transactions against a stock will also be a positive signal for investors in assessing the fundamental quality of a stock. The purpose of this study is to determine the impact offoreign capital flows (buying and selling) on stock price fluctuations. The sample used in this study were 10 companies taken from the list of stocks included in the Jakarta Islamic Index (JII). The data used is in the form of foreign position transaction data and stock closing prices in the daily period during October - December 2020. By using the panel data regression technique, it is concluded that the foreign trade position has a positive and significant effect on changes in the company's stock price. Foreign purchases will be able to give the effect of an increase in share prices, and vice versa.
\end{abstract}

Keywords

Foreign transactions, stock price fluctuations

\section{Pendahuluan}

Arus globalisasi yang telah dimulai beberapa dekade terakhir memberikan pengaruh yang besar terhadap banyak hal termasuk dalam kegiatan perekonomian. Adanya arus globalisasi membuat batas antar negara seolah -olah menjadi tidak ada. Pergerakan menuju pasar bebas global disebabkan oleh aliansi antara telekomunikasi dan ekonomi. Menurut Tapscott dan William dalam (Chandra, 2011), telekomunikasi bergerak menuju satu jaringan informasi dunia, dan begitu pula dengan kegiatan ekonomi yang menjadi satu pasar global. Kemajuan teknologi ini dan ditambah dengan adanya kebijakan liberalisasi pasar di banyak negara kemudian berdampak pada semakin meningkatnya aliran keuangan dunia. Jarak geografis menjadi tidak terlalu signifikan lagi karena semakin besarnya luas jangkauan dan kecepatan informasi yang menjadikan aktivitas keuangan global lebih efisien, termasuk dalam kegiatan pasar modal di Indonesia.

Sebagai salah satu negara berkembang, Indonesia menjadi salah satu tujuan utama dari para investor yang berasal dari negara-negara maju. Hal ini disebabkan karena salah satu karakteristik dari pasar modal di negara berkembang adalah memiliki risk premium yang lebih tinggi sehingga diharapkan akan memberikan expected return yang tinggi pula (Salomons \& Grootveld, 2003). Tingginya expectred return inilah yang kemudian menarik minat investor asing untuk turut serta berinvestasi di pasar modal Indonesia. Selain itu, perkembangan

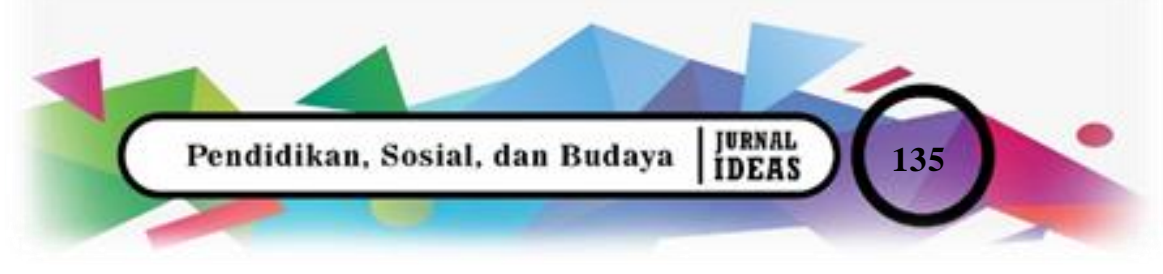




\begin{tabular}{|c|c|c|}
\hline $2 B$ & Volume & $: 7$ \\
\hline (1) $\mathrm{p}$ - & $\begin{array}{l}\text { Nomor } \\
\text { Bulan }\end{array}$ & $: 3$ \\
\hline URL: jurnal.ideaspublishing.co.id & Tahun & : 2021 \\
\hline
\end{tabular}

kondisi perekonomian Indonesia yang cukup stabil juga merupakan faktor yang dipertimbangkan oleh investor asing untuk menanamkan dana mereka ke Indonesia. Karena selain tingkat return yang diharapkan, banyak faktor yang mempengaruhi minat investasi di suatu negara antara lain faktor keamanan, stabilitas sosial dan politik, dan sebagainya (Rahayu, 2005).

Sejak keberadaan pasar modal Indonesia yang terus membaik, peranan investor asing terus meningkat, baik dari segi dana yang masuk maupun dari pelakunya. Ada beberapa karakteristik penting dari perdagangan asing di Indonesia. Wang (2000), menunjukkan bahwa perdagangan asing sangat menonjol di Bursa Efek Indonesia. Turn over asing juga sangat tinggi, hal ini sesuai dengan temuan Tesar dan Werner (1995) di beberapa pasar modal yang sudah maju. Tingginya aktivitas perdagangan asing di Indonesia membuat penelitian tentang perilaku dan dampak investor asing di Indonesia menjadi menarik untuk dilakukan.

Penelitian ini juga melihat penelitian sebelumnya dari Kang dan Stulz (1997). Kang dan Stulz menemukan bahwa investor asing lebih memilih saham- saham dari perusahaan besar. Investor asing di Jepang memegang saham dalam jumlah yang jauh lebih besar pada perusahaan-perusahaan manufaktur dengan kinerja akuntansi yang baik, tingkat leverage yang rendah, book to market yang tinggi, dan risiko tidak sistematis yang rendah dibandingkan dengan risiko pasar Jepang. Hasil penelitian menyimpulkan bahwa investor asing cenderung memilih saham dari perusahaan besar karena mereka lebih tahu mengenai keadaan perusahaan besar sehingga dapat menghindari terjadinya informasi asimetris.

Lin dan Shiu (2003), sejalan dengan Kang dan Stulz (1997), menemukan bahwa investor asing di Taiwan lebih memilih saham-saham dari perusahaan besar, tingkat ekspor yang tinggi, namun dengan tingkat book to market yang rendah. Bukti-bukti yang ditemukan dalam penelitian ini mendukung hipotesis mengenai adanya informasi asimetris antara investor asing dengan investor lokal.

Anayochukwu (2012) meneliti portofolio asing di Nigeria untuk mengidentifikasi hubungan antara investasi portofolio asing dan return pasar saham, hasil penenlitian menunjukkan bahwa investasi portofolio asing berpengaruh positif dan signifikan terhadap return pasar saham.

Hsu, Chun-Pin (2013) meneliti di pasar modal Taiwan untuk melihat kinerja saham-saham pilihan investor asing dibandingkan dengan saham-saham yang tidak disukai investor asing. Dari hasil penelitiannya ditemukan bahwa pada masa ekspansi, secara umum kinerja saham-saham yang dipilih oleh investor asing mempunyai kinerja yang lebih baik dengan memberikan return yang tinggi. Namun pada masa resesi, kinerja saham-saham yang disukai investor asing memburuk, karena para investor asing tersebut telah menarik dananya.

Penelitian yang dilakukan oleh Haryono \& Hartono (2013) yaitu untuk menguji hubungan pergerakan aliran dana investasi asing yang masuk ke pasar modal Indonesia. Dari hasil penelitiannya menunjukkan bahwa aliran dana asing yang masuk ke pasar modal Indonesia memberikan pengaruh yang positif terhadap pergera kan indeks harga saham gabungan. Penelitian yang dilakukan oleh Adiguna dan Adib (2013) menunjukkan bahwa aksi beli asing memberikan pengaruh positif terhadap harga saham menunjukkan bahwa sentimen pasar secara keseluruhan dapat dipicu oleh investor asing saat memasuki bursa. Sama halnya dengan penelitian yang dilakukan Pasaribu dan Sihombing (2015), aliran modal asing berpengaruh positif dan signifikan terhadap harga saham. Bobbi dan Haryanto (2017) juga menemukan adanya pengaruh positif signifikan antara foreign inflow terhadap return saham.

Selanjutnya, penelitian yang dilakukan oleh Surasni et al., (2019) untuk melihat aktivitas perdagangan investor asing apakah dapat mendestabilize harga di BEI. Penelitian ini mengajukan tiga hipotesis yang akan dibuktikan. Hipotesis pertama adalah investor asing akan meningkatkan diversifikasi portofolio atau disebut hipotesis base-broadening. Hipotesis kedua yaitu investor asing akan menyebabkan tekanan harga pada saham atau disebut hipotesis price pressure. Hipotesis ketiga adalah investor asing menggunakan strategi tertentu didalam perdagangannya yaitu strategi feedback trading. Dari 401 perusahaan terpilih 32 perusahaan sebagai sampel. Selanjutnya dari ketiga hipotesis yang diajukan, yang terbukti hanya hipotesis price pressure. Dengan demikian maka investor asing dapat menyebabkan destabilize harga di Bursa Efek Indonesia. berbeda halnya dengan penelitian yang dilakukan oleh Ahmad, Ahmad dan Yusniar (2018) menunjukkan bahwa aliran Investasi Asing (NFP) tidak berpengaruh terhadap IHSG.

\section{Pasar Modal}

Pasar modal merupakan tempat di mana pihak dengan dana berlebih dan pihak yang memerlukan dana melalui aktivitas jual beli berupa sekuritas yang bersifat jangka panjang (Tandelilin, 2010). Selain dapat melakukan transaksi di pasar modal negara sendiri, investor dapat melakukannya di pasar modal asing yang berupa pasar 


\begin{tabular}{ll|l} 
Volume & $: 7$ & E-ISSH: 2656-940X \\
Nomor & $: 3$ & P-ISSH: 2442-367K \\
Bulan & $:$ Agustus & URL:jurnal.ideaspublishing.co.id \\
Tahun & $: 2021$ & U.
\end{tabular}

modal internasional. Pasar modal internasional ini dilihat dari kebebasan oleh investor, broker, dan emiten dalam kegiatan investasi atau usaha dibanyak Negara (Baker, 2015).

\section{Investasi}

Investasi merupakan keterikatan atas dana atau sumber daya lainnya yang bertujuan untuk mendapatkan keuntungan di masa yang akan datang. Terbukanya kesemparan investor untuk berinvestasi di negara-negara lain diiringi dengan perkembangan pasar modal di berbagai negara berkembang (Tandelilin, 2010). Dengan investasi internasional berarti membuka kesempatan untuk mendapatkan manfaat (return) yang lebih baik daripada investasi domestik dan mengurangi risiko portofolio (Sartono, 2001).

\section{Aliran Investasi Asing}

Aliran investasi asing merupakan salah satu bentuk penerimaan aliran modal asing oleh negara. Aliran investasi asing berupa investasi portofolio yang dilakukan di pasar modal negara yang bersangkutan. Kegiatan yang dilakukan investor asing akan memperbesar peran penting untuk investor lokal sebagai informasi dan alokasi aset (Prasetiyo, 2012).

Setidaknya ada tiga penjelasan terhadap hubungan antara aliran modal asing dengan return pasar yaitu:

1. Base-broadening hypothesis

Hipotesis base-broadening, menyatakan bahwa perluasan basis investor dengan memasukkan investor asing ke dalam pasar domestik akan menyebabkan diversifikasi semakin meningkat. Adanya penambahan jumlah investor yang berinvestasi di pasar modal akan dapat meningkatkan permintaan dan likuiditas dari saham yang dijual di pasar saham (Clark dan Berko, 1997). Peningkatan diversifikasi ini akan disertai dengan turunnya risiko karena kini risiko bukan hanya ditanggung oleh investor domestik, namun juga ditanggung bersama-sama dengan investor asing (risk sharing). Peningkatan risk sharing ini disebut base broadening effect, merupakan fondasi teoritis yang sangat penting dari keuntungan liberalisasi pasar modal.

2. Price-pressure hypothesis

Aliran investasi asing dapat mempengaruhi harga saham domestik walaupun investor asing tersebut tidak memiliki informasi. Aliran tersebut dapat didorong oleh sentimen investor asing yang tidak ada hubungannya dengan faktor fundamental. Sentimen tersebut akan menyebabkan pergerakan harga saham domestik, baik naik ataupun turun. Harga akan berbalik (reversal) setelah tekanan mereda. Oleh karena itu price pressure ini disebut dampak yang temporer.

Pada penelitian yang dilakukan Clark dan Berko (1997) ditemukan bahwa peningkatan pada aliran modal asing dapat meningkatkan harga saham yang bersifat sementara(pricepressure) ataupun permanen. Terjadinya perubahan harga bersifat yang permanen akibatpembelian investor asing menunjukkan adanyapenurunan biaya modal (cost of capital) dalam jangka panjang yang disebabkan oleh pembagian risiko (risk sharing). Keuntungan dari masuknya investor asing dan terbukanya pasar adalahbertambahnya jumlah investor (base broaden-ing) bagi pasar modal negara berkembang sehingga bisa meningkatkan permintaan dan likuiditas dari saham yang dijual di bursa.

3. Positive feedback strategy atau disebut juga return chasing strategy

Berdasarkan teori feedback trader, investor membuat keputusan investasi berdasarkan pada pergerakan pasar, di mana hal tersebut dapat diidentifikasikan secara statistik dengan adanya korelasi antara invetasi asing dengan return pas ar yang terjadi pada periode - periode sebelumnya (Clark dan Berko, 1997).

Terdapat dua macam teori feedback trader yaitu positif dan negatif. Teori positive feedback trader menyatakan bahwa aliran investasi asing di pasar modal akan merespon terhadap pergerakan return pasar dengan melakukan pembelian pada saat harga mulai naik dan sebaliknya melakukan aksi jual pada s aat

harga mulai turun. Sedangkan negative feedback trader menyatakan bahwa investor akan melakukan pembelian sekuritas pada saat harga rendah atau mulai turun dan akan melakukan penjualan saat harganya tinggi atau mulai naik.

\section{Metode}

Penelitian ini menggunakan pendekatan kuantitatif dengan tujuan penelitian yang bersifat eksplanatif. Hal ini dikarenakan penelitian ini bertujuan untuk menggambarkan dan menjelaskan bagaimana dampak pembelian investor asing terhadap fluktuasi saham-saham di Bursa Efek Indonesia yang dilihat dari karakteristik

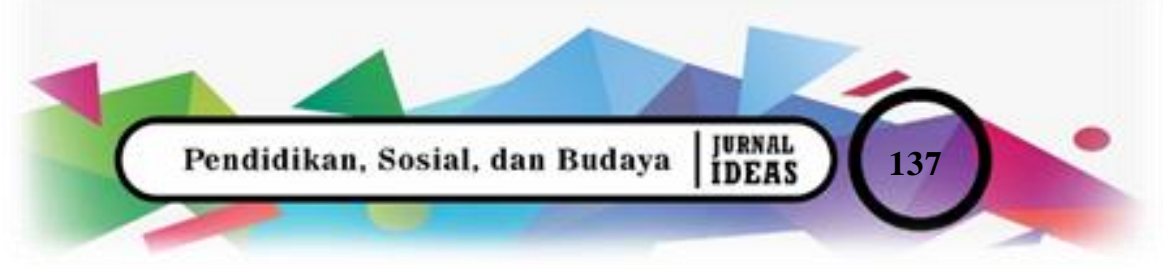


perusahaan. Berdasarkan jenis data, penelitian ini menggunakan data pooled karena mengamati beberapa perusahaan yang kemudian selanjutnya diamati selama beberapa periode. Data yang digunakan berupa data transaksi harian dari saham-saham terpilih.

Populasi dalam penelitian ini adalah saham-saham yang terdaftar di Bursa Efek Indonesia. Selanjutnya dengan pertimbangan bahwa investor asing berdasarkan beberapa penelitian sebelumnya lebih banyak masuk pada saham-saham yang berkapitalisasi besar maka sampel pada penelitian lebih diarahkan ke saham-saham yang termasuk kelompok JII-70. Alasan lain pemilihan kelompok JII-70 adalah adanya kriteria fundamental yang disyaratkan untuk saham-saham yang bisa masuk dalam kelompok ini. Dari daftar saham yang termasuk dalam kelompok JII-70 tersebut kemudian diambil sampel sebanyak 10 perusahaaan. Pengambilan sampel memerhatikan kapitalisasi masing-masing, di mana setiap kelompok diambil sampel 2 perusahaan yang memiliki kapitalisi tertinggi dengan sebaran sebagai berikut:
1. Nilai kapitalisasi $<5$ Triliun
: 2 perusahaan
2. Nilai kapitalisasi antara 5 - 10 Triliun
: 2 perusahaan
3. Nilai kapitalisasi antara $10-50$ Triliun :2 perusahaan
4. Nilai kapitalisasi antara $50-100$ Triliun :2 perusahaan
5. Nilai kapitalisasi antara $>100$ Triliun $: 2$ perusahaan

Setelah 10 sampel perusahaan ditetapkan maka kemudian dilakukan pengumpulan data transaksi asing dan harga saham perusahaan. Data yang digunakan berupa data harian dengan periode pengamatan selama bulan Oktober 2020 - Desember 2020. Selanjutnya analisis dilakukan dengan menggunakan pendekatan regresi data panel. Pendekatan ini digunakan dengan mempertimbangkan bentuk data yang berupa data pooled.

Model regresi yang akan dianalisis adalah sebagai berikut:

$$
\text { Price }_{i t}=\beta_{0}+\beta_{1} \text { Foreign }_{i t}+e_{i t}
$$

Keterangan:

Price $_{\text {it }} \quad$ : harga saham perusahaan ke-i pada periode ke-t

Foreign $_{\text {it }} \quad$ : pembelian asing (net sell/net buy) pada saham ke-i periode ke-t

$\beta_{0} \quad$ : intercept (konstanta) model regresi

$\beta_{1} \quad$ : slope (koefisien pengaruh) model regresi

\section{Hasil dan Pembahasan}

\section{Deskripsi Objek dan Variabel Penelitian}

Berdasarkan data kapitalisasi saham yang diambil saat data dikumpulkan, diperoleh 10 saham yang memiliki kapitalisasi tertinggi pada masing-masing kelompok seperti dalam tabel 1 berkut ini:

Tabel 1

Data Market Kapitalisasi (Oktober-Desember 2020)

\begin{tabular}{llll}
\hline Market Kapitalisasi & Kode Saham & Nama Perusahaan & Sektor \\
\hline$>100$ Triliun & TLKM & PT Telkom Indonesia (Persero), Tbk & Integrated Telecomunication \\
\cline { 2 - 4 } & UNVR & PT Unilever Indonesia, Tbk & Personal Care Product \\
\hline \multirow{2}{*}{$50-100$ Triliun } & CPIN & PT Charoen Pokphand Indonesia, Tbk & Fish, M eat and Poultry \\
\cline { 2 - 4 } & UNTR & PT United Tractors, Tbk & $\begin{array}{l}\text { Construction Machinery and } \\
\text { Heavy }\end{array}$ \\
\hline \multirow{2}{*}{$10-50$ Triliun } & INCO & PT Vale Indonesia, Tbk & Diversified Metal and Mineral \\
\cline { 2 - 4 } & ANTM & PT Aneka Tambang, Tbk & Diversified Metal and Mineral \\
\hline \multirow{2}{*}{ - 10 Triliun } & INAF & PT Indofarma, Tbk & Pharmeutical \\
\cline { 2 - 4 }$<5$ Triliun & SMBR & PT Semen Baturaja (Persero), Tbk & Construction Material \\
\hline \multirow{2}{*}{$<$} & ADHI & PT Adhi Kary a (Persero), Tbk & $\begin{array}{l}\text { Heavy Construction \& Civil } \\
\text { Engineering }\end{array}$ \\
\cline { 2 - 4 } & RALS & PT Ramay ana Lestari Sentosa, Tbk & Department Store \\
\hline
\end{tabular}

Sumber: Data kapitalisasi pasar Bursa Efek Indonesia (Diolah Kembali)

Dari sebaran perusahaan yang terpilih menjadi sampel berasal dari 9 sektor yang tersebar merata di mana sebanyak 8 sektor diwakili oleh 1 perusahaan/_able_dan hanya_able_yakni diversified metal and mineral yang diwakili oleh 2 perusahaan.

Adapun besaran transaksi yang dilakukan oleh investor asing pada 10 saham ini selama bulan Oktober 2020-Desember cukup bervariasi. Saham yang banyak ditransaksikan oleh asing selama periode ini adalah 


$\begin{array}{ll}\text { Volume } & : 7 \\ \text { Nomor } & : 3 \\ \text { Bulan } & : \text { Agustus } \\ \text { Tahun } & : 2021\end{array}$

saham PT Telekomunikasi Indonesia (Persero), Tbk dengan rata-rata nilai transaksi asing diatas 400 milyar per bulan. Pada bulan Oktober 2020, asing mencatatkan posisi net sell sebesar 67,95 milyar rupiah. Pada bulan November investor asing mencatatkan posisi net buy sebesar 63,88 milyar rupiah dan pada bulan Desember 2020 investor asing kembali mencatatkan posisi net sell sebesar 42,06 milyar rupiah.

Adapun saham yang paling sedikit ditransaksikan oleh investor asing adalah saham PT Semen Baturaja, Tbk dengan rata-rata transaksi asing selama bulan Oktober 2020 hanya sebesar kurang lebih 150 juta rupiah yang kemudian mengalami peningkatan menjadi 5,2 milyar pada bulan November 2020 dan meningkat lagi menjadi 19,1 milyar pada bulan Desember 2020. Total posisi beli dan jual investor asing untuk setiap saham selama bulan Oktober-Desember 2020 dapat dilihat dalam tabel 2 berikut ini:

Tabel 2

Data Transaksi Asing Periode Oktober-Desember 2020

\begin{tabular}{lllllll}
\hline \multirow{2}{*}{ Kode } & Oktober $($ Rp000) & \multicolumn{3}{l}{ November (Rp000) } & \multicolumn{2}{l}{ Desember (Rp000) } \\
\cline { 2 - 7 } & Foreign Buy & Foreign Sell & Foreign Buy & Foreign Sell & Foreign Buy & Foreign Sell \\
\hline TLKM & $169,163,163$ & $237,114,576$ & $352,827,185$ & $288,951,371$ & $200,363,434$ & $242,425,127$ \\
\hline UNVR & $32,745,340$ & $27,668,948$ & $42,884,139$ & $53,672,982$ & $34,266,685$ & $49,354,327$ \\
\hline CPIN & $7,596,216$ & $7,823,387$ & $21,591,746$ & $23,923,854$ & $18,009,850$ & $29,591,788$ \\
\hline UNTR & $22,661,129$ & $37,920,152$ & $50,007,568$ & $61,646,013$ & $79,960,160$ & $60,179,228$ \\
\hline INCO & $9,494,671$ & $12,265,977$ & $16,427,614$ & $10,432,761$ & $30,656,884$ & $24,860,829$ \\
\hline ANTM & $9,981,520$ & $14,124,281$ & $22,693,304$ & $33,573,857$ & $77,738,362$ & $64,465,215$ \\
\hline INAF & 262,864 & 183,309 & 151,238 & 194,952 & $3,169,575$ & $2,877,847$ \\
\hline SMBR & 74,676 & 87,518 & $2,648,882$ & $2,655,086$ & $9,486,109$ & $9,791,067$ \\
\hline ADHI & 324,162 & 795,969 & $1,979,032$ & $3,057,571$ & $8,944,318$ & $9,315,478$ \\
\hline RALS & 818,646 & 986,139 & $4,646,407$ & $5,583,565$ & $4,898,606$ & $5,055,059$ \\
\hline Sur
\end{tabular}

Sumber: Statistik Transaksi Harian Bursa Efek Indonesia (Diolah Kembali)

\section{Pengaruh Transaksi Asing terhadap Fluktuasi Harga}

Hasil model regresi untuk pengaruh pembelian asing terhadap harga saham dari 10 perusahaan yang diamati adalah sebagai berikut:

$$
\begin{array}{ll}
\text { Price }_{i t}= & 2,44+0,0043(\text { Foreign })+e \\
S E & 0,12540,0019 \\
t \text {-stat } & 19,4822,177 \\
& (0,000)(0,029) \\
\text { F-stat } & 4,395 \\
& (0,000) \\
R^{2} & 0,771
\end{array}
$$

Dari model regresi diatas dapat ditafsirkan beberapa hal berikut.

1. Rata-rata perubahan harga saham dari 10 perusahaan yang diamati selama bulan Oktober 2020 hingga Desember 2020 adalah sebesar 2,44 persen.

2. Pembelian asing memiliki pengaruh yang positif terhadap perubahan harga saham. Jika asing dalam posisi net buy maka harga saham akan cenderung meningkat. Sebaliknya jika asing dalam posisi net s ell maka harga saham akan cenderung turun.

3. Besar pengaruh posisi asing untuk setiap 1 miliar net posisi (buy atau sell) adalah sebesar 0,0043. Dengan demikian jika asing mencatatkan posisi net buy sebesar 1 miliar maka akan mampu meningkatkan harga saham sebesar 0,0043 persen. Sebaliknya untuk setiap posisi net sell sebesar 1 miliar maka harga saham akan terkoreksi sebesar 0,0043 persen.

Selanjutnya, hasil pengujian model secara keseluruhan menghasilkan nilai F-hitung sebesar 4,395 dengan nilai signifikansi sebesar 0,000. Nilai siginifikansi ini lebih kecil dari nilai alpha pada tingkat $1 \%$ sehingga Ho ditolak. Dengan demikian dapat disimpulkan bahwa pada tingkat kepercayaan 99\%, model pengaruh pembelian asing terhadap harga saham telah fit dengan data yang ada. 


\begin{tabular}{c|ll} 
E-ISSH: 2656-940X & Volume & $: 7$ \\
Nomor & $: 3$ \\
Bulan & $:$ Agustus \\
URL: jurnal.ideaspublishing.co.id & Tahun & $: 2021$
\end{tabular}

Adapun pengujian secara parsial untuk pengaruh dari pembelian asing terhadap harga saham memberikan nilai t-hitung sebesar 2,177 dengan nilai signifikansi sebesar 0,029. Nilai signifikansi ini lebih kecil dari alpha pada tingkat 5\% sehingga Ho ditolak. Dengan demikian dapat disimpulkan bahwa pada tingkat kepercayaan 95\%, variabel pembelian asing berpengaruh positif dan signifikan terhadap perubahan harga saham.

Adapun nilai koefisien determinasi yang dihasilkan oleh model regresi adalah sebesar 0,771. Ini berarti sebesar 77,1\% perubahan harga saham dari 10 perusahaan yang diamati selama bulan Oktober 2020-Desember 2020 dipengaruhi oleh posisi pembelian asing, sedangkan sis anya sebesar 22,9\% dipengaruhi oleh faktor lain.

Periode Oktober-Desember 2020 merupakan periode yang krusial dalam transaksi pasar modal. Karena pada periode ini terdapat hipotesis akan terjadinya window dressing oleh para investor institusi terutama pengelola dana (manager fund) dengan maksud untuk menjaga kinerja portofolio yang dikelola. Meskipun masih menimbulkan perdebatan, peristiwa window dressing memang cukup sering terjadi bukan hanya di Indonesia namun juga di bursa-bursa lain di dunia. Selain adanya faktor window dressing, pada periode Oktober 2020Desember 2020 bisa dikatakan periode recovery saham-saham yang pada awal tahun banyak yang terkoreski sangat dalam akibat adanya kekhawatiran akan dampak pandemi. Namun ketikan data kondisi ekonomi kuartal III/2020 mulai dirilis dan dampaknya sudah sesuai perkiraan maka banyak saham-saham yang kembali menguat. Banyaknya saham yang terkoreksi signifikan ini tenttnya melmiliki potensi return di pasar saham di Indonesia pada masa yang akan datang. Karena semakin dalam koreksi yang terjadi maka potensi return yang nanti akan diperoleh juga cukup tinggi. Apalgi ditambah dengan membaiknya inidikator makro di masa mendatang seperti pertumbuhan ekonomi, profitabilitas emiten di Bursa Efek Indonesia yang semakin besar, serta indikator ekonomi makro lain yang kokoh dan terjaga di level yang aman. Hal tersebut sesuai dengan teori positiffeedback trader di mana para investor asing dalam menanamkan investasinya didalam suatu pasar modal melihat seberapa besar return yang dapat dihasilkan dari pasar modal tersebut karena dapat digunakan sebagai ekspektasi return yang akan di dapatkan di masa yang akan dating nanti. Hasil tersebut membuktikan bahwa aliran investasi asing dalam jumlah tertentu akan menyebabkan peningkatan harga secara permanen, yang menunjukkan bahwa terjadi penurunan biaya modal (cost of capital)

\section{Simpulan}

Berdasarkan analisis hasil penelitian yang diperoleh dapat diambil kesimpulan sebagai berikut.

1. Pembelian asing berpengaruh terhadap return saham. Oleh karena itum perubahan yang terjadi pada posisi investasi asing akan menentukan perubahan harga saham. Perubahan return pasar akibat dampak goncangan tersebut secara kumulatif akan menyebabkan terjadinya kenaikan harga aset secara permanen.

2. Posisi pembelian asing bisa disebabkan oleh banyak faktor diantaranya ekspektasi akan return yang diperoleh di masa mendatang dan ekspektasi mengenai kondisi makro di masa depan.

Memerhatikan dampak posisi pembelian asing terhadap harga saham maka kepada investor pasar modal dapat disarankan beberapa hal sebagai berikut.

1. Bagi investor yang memiliki time horizon yang pendek (kurang dari 1 tahun), posisi pembelian asing bisa menjadi salah satu alternatif indikator yang bisa digunakan dalam berinvestasi di pasar modal. Dengan memanfaatkan perubahan posisi asing, diharapkan investor dapat mengoptimalkan return dari portofolio yang mereka miliki.

2. Untuk lebih mengoptimalkan return portofolio, investor juga sebaiknya melakukan analisa terhadap kondisi fundamental perusahaan dan hanya berinvestasi pada perusahaan-perusahaan yang memiliki ekpektasi positif di masa mendatang.

\section{Daftar Rujukan}

Adiguna, K. A., \& Adib, N. (2013). Analisis Pengaruh EPS, PER, dan Dividend Yield serta Aliran Dana Asing terhadap Perubahan Harga Saham Bluechip dan Harga Saham Lini Kedua di Bursa Efek Indonesia Tahun 2009-2011. Jurnal Ilmiah Mahasiswa FEB, 1(2), 1-25.

Ahmad, A. A., \& Yusniar, M. W. (2018). Pengaruh Pasar Modal Asing dan Aliran Investasi Asing Terhadap Indeks Harga Saham Gabungan di Bursa Efek Indonesia Periode Tahun 2013-2017. Jurnal Sains Manajemen Dan Kewirausahaan, 2(2), 88-95. http://ppjp.ulm.ac.id/journal/index.php/jsmk

Anayochukwu, O. B. (2012). The Impact of Stock Market Returns on Foreign Portfolio Investment in Nigeria. IOSR Journal of Business and Management, 2(4), 10-19. https://doi.org/10.9790/487x-0241019

Baker, B. (2015). Pasar Modal Internasional. https://Www.Academia.Edu/27343703. 


$\begin{array}{ll}\text { Volume } & : 7 \\ \text { Nomor } & : \mathbf{3} \\ \text { Bulan } & : \text { Agustus } \\ \text { Tahun } & : 2021\end{array}$

E-ISSH: 2656-940X 구

P-ISSH: 2442-367X

Tahun : 2021

URL: jurnal.ideaspublishing.co.id

Bobbi, \& Haryanto, A. M. (2017). Analisis Pengaruh Foreign Inflow, Inflasi, Suku Bunga dan Kurs pada Return Saham (Studi kasus pada sektor keuangan periode Juli 2016 - Januari 2017). Diponegoro Journal Of Management, 6(2), 1-11.

Chandra, R. (2011). Analisis Pemilihan Saham oleh Investor Asing di Bursa Efek Indonesia. Jurnal Ilmu Administrasi Dan Birokrasi, 17(2), 101-113.

Clark, J., \& Berko, E. (1997). Foreign Investment Fluctuations and Emerging Market Stock Returns: The Case of Mexico. In Serve Bank of New York: Staff Reports. https://doi.org/10.2139/ssrn.993813

Haryono, I., \& Hartono, J. (2013). Analisis Hubungan Aliran Dana Investor Asing terhadap Perilaku "Herding” di Sahamsaham LQ 45 Bursa Efek Indonesia. Repositori.Ugm.Ac.Id.

Hsu, C.-P. (2013). The Influence of Foreign Portfolio Investment on Domestic Stock Returns: Evidence From Taiwan. The International Journal of Business and Finance Research, 7(3), 1-12.

Kang, J. K., \& Stulz, R. M. (1997). Why is there a home bias? An analy sis of foreign portfolio equity ownership in Japan. Journal of Financial Economics. https://doi.org/10.1016/S0304-405X(97)00023-8

Lin, C. H., \& Shiu, C. Y. (2003). Foreign ownership in the Taiwan stock market - An empirical analysis. Journal of Multinational Financial Management. https://doi.org/10.1016/S1042-444X(02)00021-X

Pasaribu, D., \& Sihombing, D. (2015). Analisis Pengaruh Inflasi, Suku Bunga dan Aliran Modal Asing Terhadap Harga Saham Dengan Kinerja Keuangan dan Nilai Kurs Sebagai Variabel Intervening. Majalah Ilmiah Methoda, 5(1).

Prasetiyo, D. H. (2012). Lead-Lag Dan Volatility Spill Over Aliran Investasi Asing Pada Perdagangan Saham Di Bursa Efek Indonesia Tahun 2009 - 2012. Jurnal Bisnis Strategi, 21(1), 46-61. https://doi.org/10.14710/jbs.21.1.46-61

Rahayu, N. (2005). Kebijakan Investasi Asing (Foreign Direct Investment) di Indonesia dan Vietnam. Jurnal Ilmu Administrasi Dan Organisasi, Bisnis \& Birokrasi, 13(1).

Salomons, R., \& Grootveld, H. (2003). The equity risk premium: Emerging vs. developed markets. Emerging Markets Review, 4(2), 121-144. https://doi.org/10.1016/S1566-0141(03)00024-4

Sartono, R. A. (2001). Manajemen Keuangan Internasional. BPFE.

Surasni, N. K., Bisma, I. D. G., Hermanto, Burhanudin, \& Negara, I. K. (2019). Investor Asing Dan Return Pasar: Apakah Investor Asing Mendestabilize Bursa Efek Indonesia. Jmm Unram - Master of Management Journal, 8(1), 73-85. https://doi.org/10.29303/jmm.v8i1.377

Tandelilin, E. (2010). Portofolio dan Investasi Teori dan Aplikasi. Kanisius.

Tesar, L. L., \& Werner, I. M. (1995). Home bias and high turnover. Journal of International Money and Finance. https://doi.org/10.1016/0261-5606(95)00023-8

Wang, J. (2000). Foreign Trading and Market Volatility in Indonesia. Working Paper. https://doi.org/10.2139/ssrn.258773 
Tahun : 2021 